\title{
2 軸繰り返し荷重下における角回し溶接継手の疲労挙動
}

（第 2 報）

-2 軸荷重レンジ比および横方向繰り返し圧縮荷重の影響一

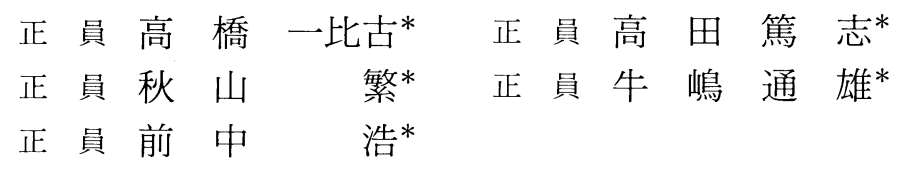

Fatigue behaviour of a box-welded joint under biaxial cyclic loads (2nd report)

-Effects of biaxial load range ratio and cyclic compressive loads in the lateral direction-

\author{
by Ichihiko Takahashi*, Member \\ Shigeru Akiyama*, Member \\ Hiroshi Maenaka*, Member
}

\author{
Atsushi Takada*, Member \\ Michio Ushijima*, Member
}

\section{Summary}

Biaxial fatigue behaviour of a box-welded (wrap-around) joint in a JIS SM $400 \mathrm{~B}$ steel (12 mm thick plate) was studied using a multiaxial fatigue test facility. For the specimen, two stiffeners were attached to a main plate by a $\mathrm{CO}_{2}$ semi-automatic welding procedure. Residual stress measurements and finite element analyses (FEA) were also done. Fatigue tests were performed under both uniaxial and biaxial cyclic loads, and the results were comparatively examined. In the biaxial fatigue tests, special concerns were focused on effects of biaxial load range ratio and compressive cyclic loads in the lateral direction.

It was found that the direction of fatigue crack propagation under biaxial cyclic tensile loads, which have a phase difference of $\pi$, changes according to the biaxial load range ratio, $R_{\mathrm{xy}}=\Delta P_{\mathrm{x}} / \Delta P_{\mathrm{y}}$, and the crack direction was estimated from the value of the stress range at a distance of $5 \mathrm{~mm}$ from the weld toe, $\Delta \sigma_{5}$, calculated by the FEA. In the load cases where $R_{x y}$ was less than 0.56 , fatigue cracks propagated along the weld toe in the $\mathrm{x}$-direction because $\Delta \sigma_{\mathrm{y}}$ at that location exceeded $\Delta \sigma_{\mathrm{x}}$ at the boxing weld toe.

As a general result in this study, the crack initiation life, $N_{\mathrm{c}}$, and the failure life, $N_{\mathrm{f}}$, in the biaxial tests were well related to those in the uniaxial tests by using $\Delta \sigma_{5}$, whereas the location and direction of $\Delta \sigma_{5}$ should be properly chosen according to the $R_{x y}$ value and the failure form (crack direction). And it was concluded that an increase in $\Delta \sigma_{5}$, which is induced by the Poisson's effect from the out-of

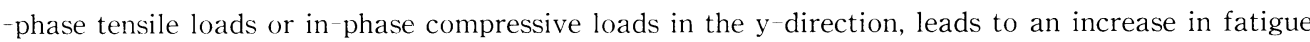
damage, and the damage increase can be successfully estimated from the uniaxial fatigue test data.

\footnotetext{
記 号

E:ヤング率

$N_{\mathrm{c}}: 5 \%$ drop 法によるき裂発生寿命

$N_{\mathrm{f}}$ : 破断寿命
}

連輸省 船舶技術研究所

Ship Research Institute

原稿受理平成 12 年 7 月 7 日

秋季講演会に打いて講演 平成 12 年 11 月 16,17 日

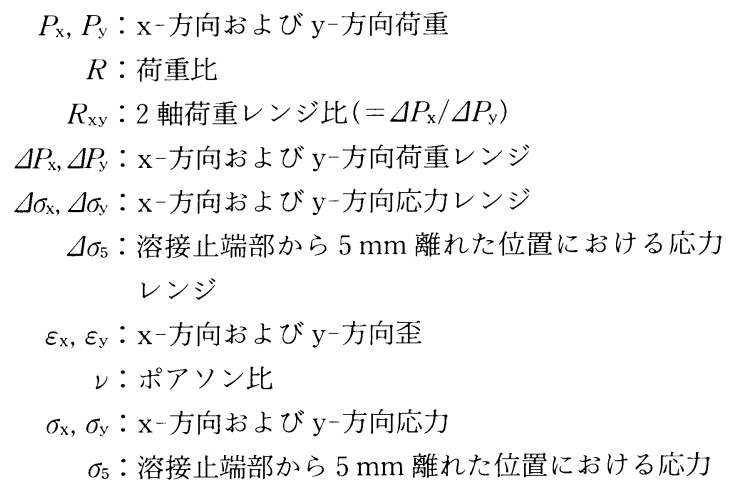




\section{1.は じめに}

船体構造には, 重力, 波浪外力, 慣性力等, 様々な外力 が様々な方向から複合的に作用する。また, 板骨構造の取 り合い部等, 応力状態が 3 次元的になる部位も数多く存在 する。従って, 船体構造部材の疲労強度や疲労寿命を論じ る場合, これら複合荷重条件や多軸応力状態の影響を明ら かにして扔く必要がある。これまでにも，直交 2 軸の繰り 返し引張荷重による疲労を実験的に扱った研究はあるが, 切欠付きの母材に関するものが多く，溶接継手を対象とし たものは少ない1)。このような観点から, 当所では Photo 1 に示すような複合荷重試験装置を整備し, 様々な複合荷 重をモデル化した疲労試験を行うことにより, 溶接構造物 の疲労寿命に及ほす複合荷重の影響に関する知識の集積を はかっている。その第一段階として, 既報2),3)では, 主に 位相差 $\pi$ の 2 軸繰り返し引張荷重を受ける角回し溶接継 手の疲労挙動について検討した。その結果, 横方向の繰り 返し引張荷重はポアソン効果により止端部の応力レンジを 増大させ, 疲労被害度を増大させること, また, その度合 いは 1 軸疲労試験における応力レンジの増大がもたらすも のとほぼ同等であることが判明した。参照応力としては, 止端部から $5 \mathrm{~mm}$ の位置における応力レンジ $\Delta \sigma_{5}$ を用い ることにより, 横方向荷重の影響を応力レンジ中に包含 し，1軸データと 2 軸データをうまく関連づけられること がわかった。その後, 2 軸荷重レンジ比㧍よび横方向繰り 返し圧縮荷重の影響について検討し，若干の知見が得られ たのでここに報告する。

\section{2. 実験}

\section{1 供試材および試験体}

供試材は 1 軸試験体 (基礎デー夕取得用), 2 軸試験体 ともに溶接構造用鋼 SM $400 \mathrm{~B}$ （板厚 $12 \mathrm{mm）で,} \mathrm{ミルシ}$ 一トによる化学成分および機械的性質を Table 1,2 に示 す。試験体は, 主板の中央部・表裏面にリブ板（スティフ ナー）を角回し溶接により接合したもので，1軸および 2 軸試験体の形状寸法を, Fig. 1(a), (b ) にそれぞれ示 す。

溶接は $0.9 \mathrm{~mm} \phi$ のワイヤー（神戸製鋼製 $\mathrm{MG}-50 \mathrm{~T}$ ) による $\mathrm{CO}_{2}$ 半自動溶接で実施した。溶接条件を Table 3 に示す。目標脚長 $6 \mathrm{~mm} \times 6 \mathrm{~mm}$ の 1 パス溶接とし, Fig. 1 中に示す通り, 溶接の始終端は角回し部を避けるように した。

\section{2 残留応力測定}

1 軸試験体および 2 軸試験体につき，溶接止端部近傍の 残留応力を, 歪ゲージを用いた応力弛緩法により測定し た。まず, 直交 2 軸ゲージ（ゲージ長 $2 \mathrm{~mm}$ ）をFig. 2 の 上部に黒丸で示す位置（主板の片面）に貼付し, 角回し溶 接止端部近傍の $\mathrm{x}$-方向残留応力を測定した。Fig. 2 に扔

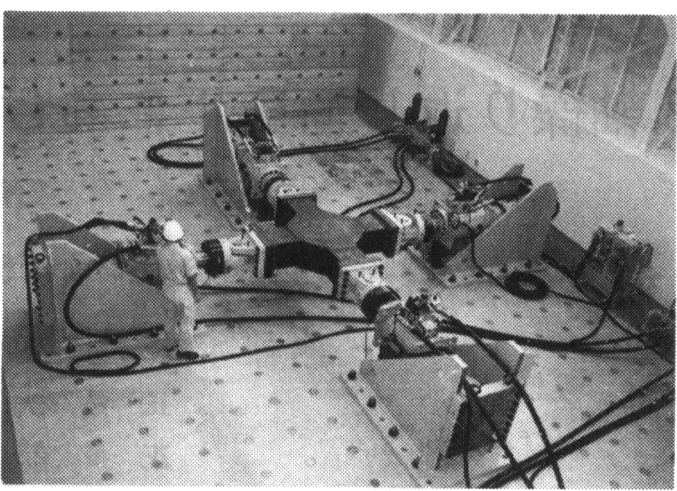

Photo 1 Multiaxial fatigue test facility

Table 1 Chemical composition of SM 400 B

\begin{tabular}{cccccc}
\hline Composition & C & Si & Mn & P & S \\
\hline Weight \% & 0.13 & 0.20 & 0.69 & 0.024 & 0.008 \\
\hline & & & & \multicolumn{3}{c}{ Remainder Fe }
\end{tabular}

Table 2 Mechanical properties of SM 400 B

\begin{tabular}{ccc}
\hline $\begin{array}{c}\text { Tensile Strength } \\
(\mathrm{MPa})\end{array}$ & $\begin{array}{c}\text { Yield Stress } \\
(\mathrm{MPa})\end{array}$ & $\begin{array}{c}\text { Elongation } \\
(\%)\end{array}$ \\
\hline 432 & 283 & 30 \\
\hline
\end{tabular}

いて, 横軸ゼロの位置が, リブの長手方向中心線上, 溶接 止端部から $5 \mathrm{~mm}$ のところ（図の $\mathrm{A}$ 点）に相当するが，1 軸・2 軸試験体ともに, $\mathrm{x}$-方向の残留応力はほぼ降伏応力 に達している。A 点から $\mathrm{y}$-方向に離れるにつれて残留応 力は急激に減少し, $20 \mathrm{~mm}$ で半減, $40 \mathrm{~mm}$ 離れると 2 軸 試験体ではほぽゼロ，1軸試験体では圧縮側となってい る。压縮側の残留応力を横軸 $60 \mathrm{~mm}$ の位置で比較してみ ると，1軸試験体で-151 MPa，2軸試験体でー48 MPa と, 前者の方が約 3 倍の值を示しており, その近傍におけ る残留応力分布の勾配もやや急峻となっている。

2 軸試験体については更に, Fig. 3 の上部に黒丸で示す 位置（主板の片面）にも歪ゲージを貼付し，x-方向およ びy-方向残留応力を測定している。リブ長手方向の溶接 止端部に対しては, 主に $\mathrm{y}$-方向の繰り返し応力が疲労応 力となる。Fig. 3 で $\mathrm{y}$-方向の残留応力をみると, 中央の B 点を含め, 両側に $20 \mathrm{~mm}$ 離机てもほぼ降伏しており, 更に離れると徐々に低下するものの, 引張の残留応力域は リブの終端部まで続いている。一方, $\mathrm{x}$ 一方向（溶接線方 向）の残留応力は $\mathrm{B}$ 点でほぼ降伏応力に達しており， $\mathrm{x}-$ 方向に離れるにつれて緩やかに減少するが, B 点から 120 $\mathrm{mm}$ の位置でも引張側となっている。

Fig. 2 と Fig. 3 との間に見られるような, 疲労応力方向 


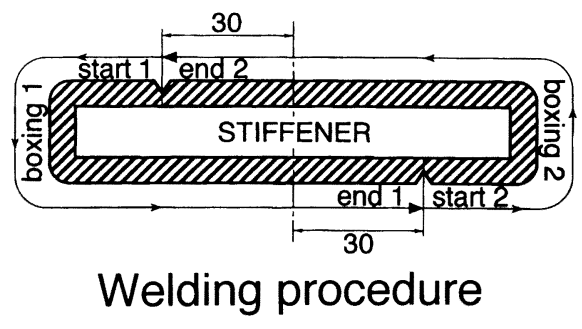

(a)
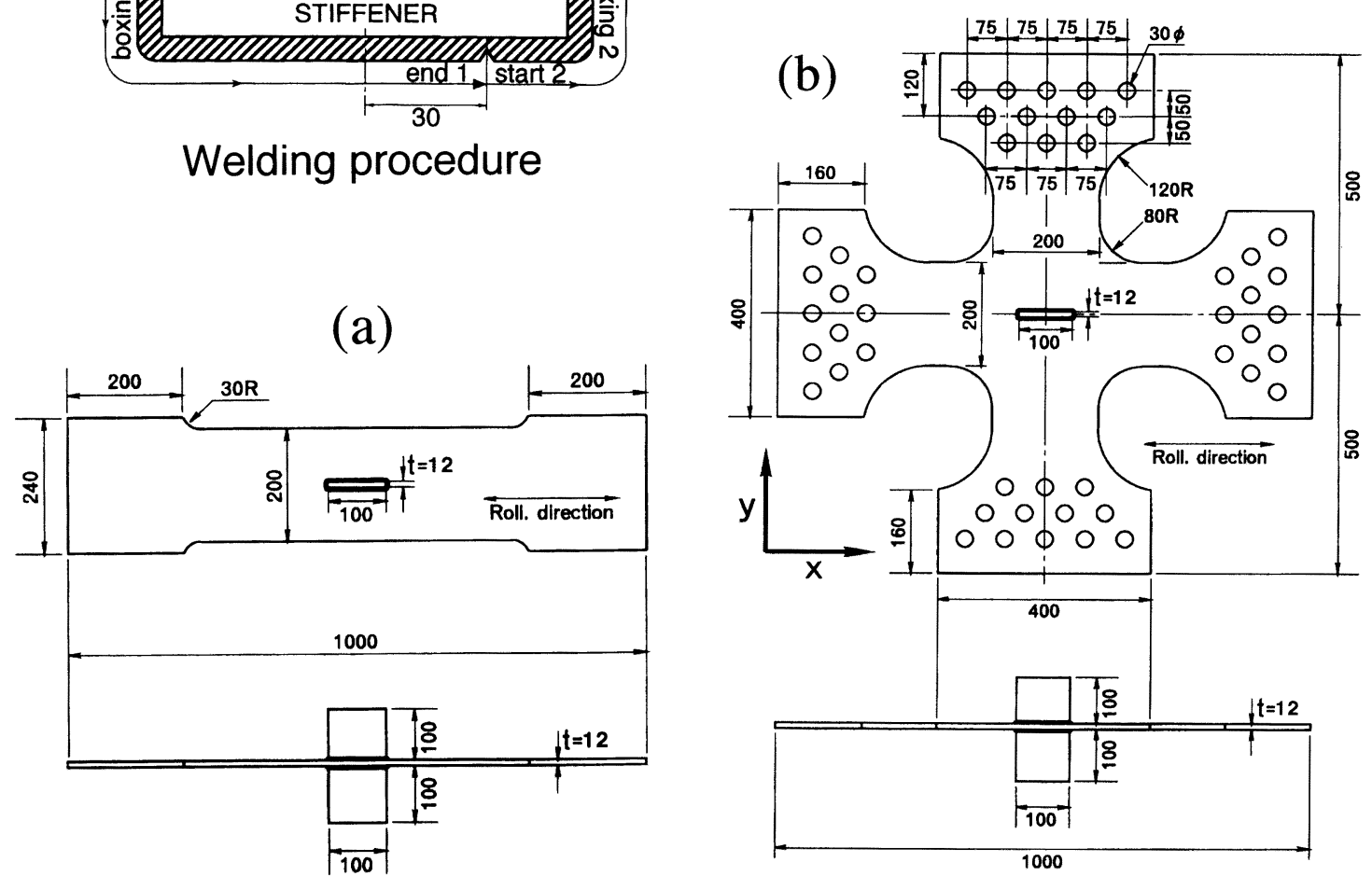

Fig. 1 Welding procedure and designs of (a) uniaxial and (b) biaxial fatigue test specimens; dimensions in $\mathrm{mm}$.

Table 3 Welding conditions

\begin{tabular}{llllll}
\hline $\begin{array}{l}\text { Type of } \\
\text { welding }\end{array}$ & $\begin{array}{l}\text { Number of } \\
\text { pass }\end{array}$ & $\begin{array}{l}\text { Filler } \\
\text { metal }\end{array}$ & $\begin{array}{l}\text { Welding } \\
\text { current }\end{array}$ & $\begin{array}{l}\text { Welding } \\
\text { voltage }\end{array}$ & $\begin{array}{l}\text { Welding } \\
\text { speed }\end{array}$ \\
\hline \hline $\begin{array}{l}\mathrm{CO}_{2} \\
\text { semi-auto }\end{array}$ & 1 & $\begin{array}{c}\text { MG-50T } \\
(\phi 0.9 \mathrm{~mm})\end{array}$ & $\begin{array}{c}180 \sim 190 \\
{[\mathrm{~A}]}\end{array}$ & $\begin{array}{c}27 \sim 28 \\
\mathrm{~N}]\end{array}$ & $\begin{array}{c}12 \\
{[\mathrm{~cm} / \mathrm{min}]}\end{array}$ \\
\hline
\end{tabular}

の残留応力分布における相違は, き裂発生後のき裂伝播速 度および最終的な破断寿命に影響を及ほすと考えられ，寿 命評価の際には重要な要素となる。

\section{3 有限要素解析}

2 軸試験体の溶接止端部近傍の歪および応力分布を求め るため, 弾性有限要素解析（以下FEA）を行った。FEA には, 汎用構造解析コードMARC（K 6.2）を用いた。 要素は 8 節点アイソパラメトリック六面体要素とし, 対称 性を考慮して 8 分割モデルを用いた（モデルの詳細および 表面の歪を求める方法については前報2) 参照)。Fig. 4 に, 角回し溶接止端部から $5 \mathrm{~mm}$ 離れた位置（Fig. 2 の A 点）
における $\mathrm{x}$-方向歪範囲について, FEA の結果と疲労試験 中の歪ゲージによる測定值とを比較して示す。 $\mathrm{y}$-方向荷 重 $P_{\mathrm{y}}$ の正負に関わらず, 両者は比較的良く一致してお り，局所的な歪に対して FEAによる評価が有効であるこ とがわかる。全体的な傾向として計算值の方が若干大きめ なのは, 実際のビード形状と FEモデルとの微妙な相違 (特に脚長) によるものと考えられる。

\section{4 疲労試験}

\subsubsection{1 軸疲労試験}

疲労寿命評価の基礎データを得るために， 1 軸試験体の 定振幅疲労試験を行った。試験は, 固定式の電気一油圧省 


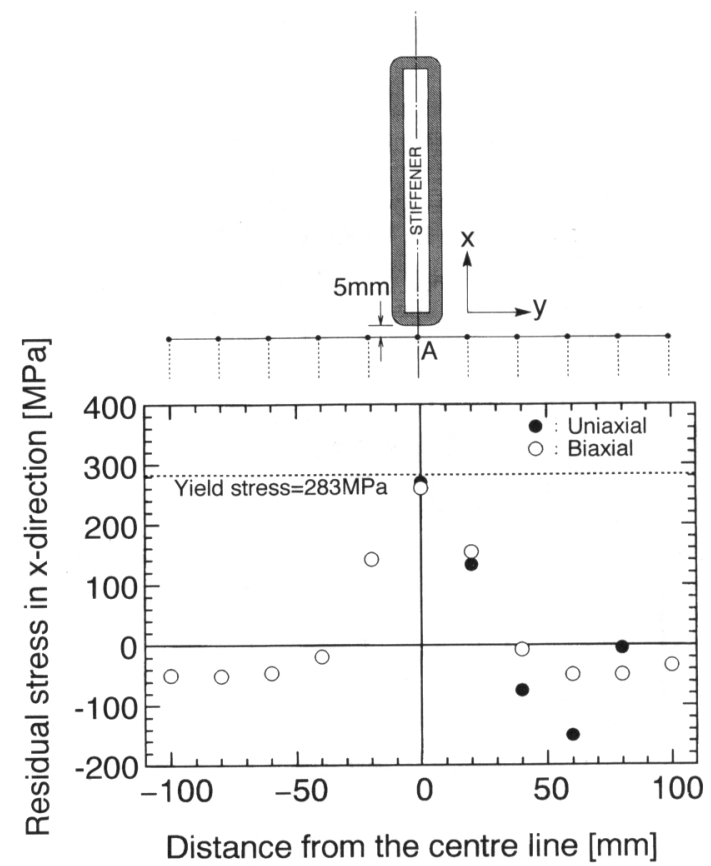

Fig. 2 Strain gauge locations and results of residual stress measurements for uniaxial and biaxial fatigue test specimens.
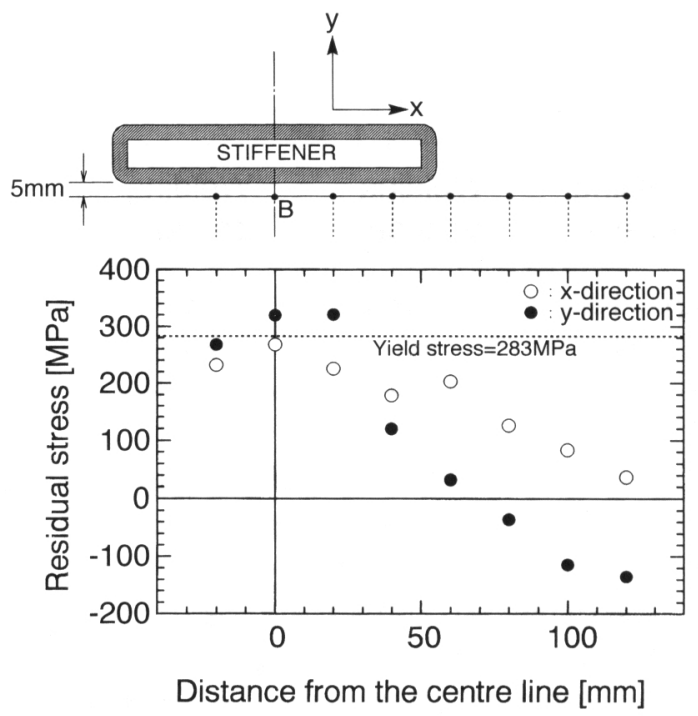

Fig. 3 Strain gauge locations and results of residual stress measurements for biaxial fatigue test specimen.

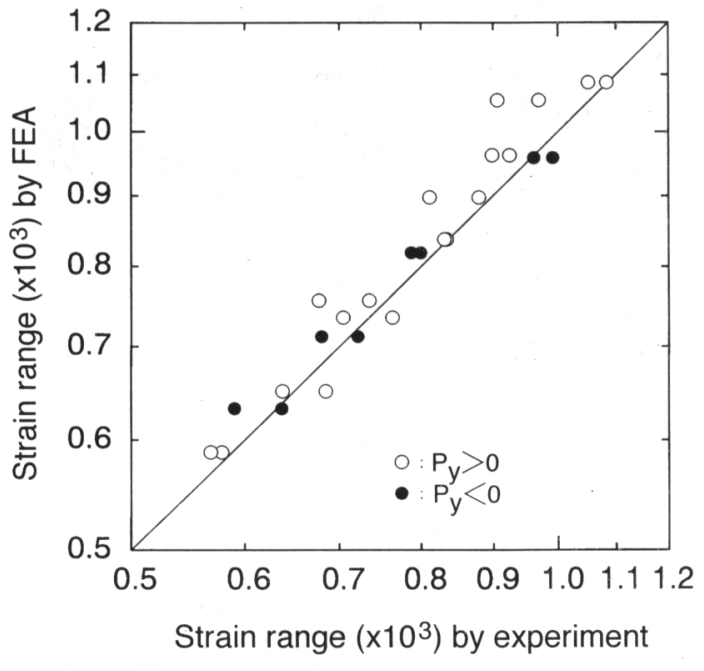

Fig. 4 Strain range comparisons between FEA results and measured values.

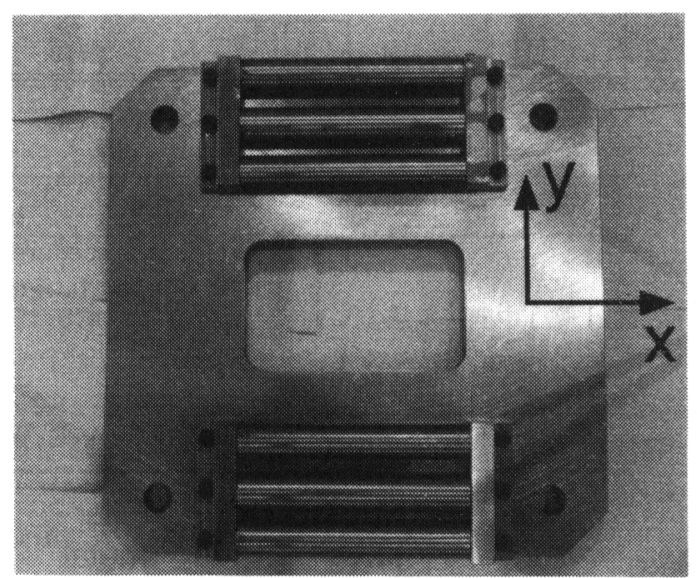

Photo 2 Anti-buckling jig

一ボ疲労試験機（動的容量 $1000 \mathrm{kN}$ ) を用い, 荷重比 $R=0$ の完全片振り荷重制御（荷重波形は周波数 $1 \sim 2 \mathrm{~Hz}$ の正弦波) で行った。

\section{4 .22 軸疲労試験}

動的容量 $1000 \mathrm{kN}$ の電気一油圧サーボ式アクチュエー 夕 4 台を対称な十文字に配置し, 試験体の中点を保持した 直交 2 軸の荷重制御疲労試験を実施した（制御の詳細は既 報 ${ }^{2,3)}$ 参照)。今回は特に, $\mathrm{y}$-方向繰り返し压縮荷重を作 用させるため, Photo 2 に示すような座屈防止治具を製作 した。試験に際しては，y-方向に転がるローラーを介し て試験体を 2 枚の治具でサンドイッチ状に挟み, 治具の四 隅をボルト・ナットで締結し，y-方向圧縮荷重作用時の 面外変形を抑制した。 


\section{3. 疲労試験結果および解析}

\subsection{1 軸疲労試験結果}

矢島ら ${ }^{4)}$ は, 冬種の基本要素継手についての疲労試験デ ー夕と実構造物の疲労データとを結びつける照査応力とし て, 溶接止端部から $5 \mathrm{~mm}$ の位置に打ける応力レンジ $\Delta \sigma_{5}$ を用いることを提案し，いくつかの構造モデルについてそ の有効性を示している。本研究に扔いても，1軸および2 軸疲労試験データの整理には主としてこの $\Delta \sigma_{5}$ を用い， 2 軸試験における $\mathrm{y}$-方向荷重の効果を定量的に考虑し，1 軸データから寿命予測を行う上で有効なパラメーータである ことを示してきた ${ }^{21.3)}$ 。詳細は既報にゆずるが，1 軸疲労 試験の結果, 角回し溶接止端部から $5 \mathrm{~mm}$ の位置（Fig. 2 の A 点) におけるx-方向応力レンジ $\Delta \sigma_{5}$ と $5 \%$ drop 法 ${ }^{51}$ によるき裂発生寿命 $N_{\mathrm{c}}$ および破断寿命 $N_{\mathrm{f}}$ の)関係式とし て, 最小自乗法近似により次の 2 式が得られている。

$$
\begin{aligned}
& N_{\mathrm{c}}=1.64 \times 10^{13} \cdot \Delta \sigma_{5}{ }^{-3.71} \\
& N_{\mathrm{f}}=1.34 \times 10^{12} \cdot \Delta \sigma_{5}{ }^{-2.85}
\end{aligned}
$$

(1)式抢よび ( 2 )式は， 2 軸疲労試験の寿命評価に抢け る基礎データとして後で使用する。

\subsection{2 軸疲労試験結果}

Table 4 に，2軸疲労試験の試験条件抢よび結果をまと めて示す。表中, $N_{(40 \mathrm{~mm})}, N_{(60 \mathrm{~mm})}, N_{(80 \mathrm{~mm})}$ とあるのは, 角 回し溶接止端部から発生し，ほぼ $\mathrm{y}$-方向に伝播したき裂 の長さが，それぞれ $40 \mathrm{~mm}, 60 \mathrm{~mm}, 80 \mathrm{~mm}$ に達したと きのサイクル数であり, 各き裂長の検出には CD ゲージを 用いた。ここで, 各試験シリーズの荷重波形模式図を Fig. 5 に示す。実際の試験では，アクチュエー夕に取り付 けられたスイベル・ジョイントの遊びを避けるため，除荷 時の荷重を完全にはゼロとせず，引張側，圧縮側ともに $15 \sim 20 \mathrm{kN}$ 程度の荷重を残した。また, 荷重波形は周波
数 $1.2 \sim 2.5 \mathrm{~Hz}$ の正弦波形とした。各シリーズにおける 荷重設定の詳細は以下の通りである。
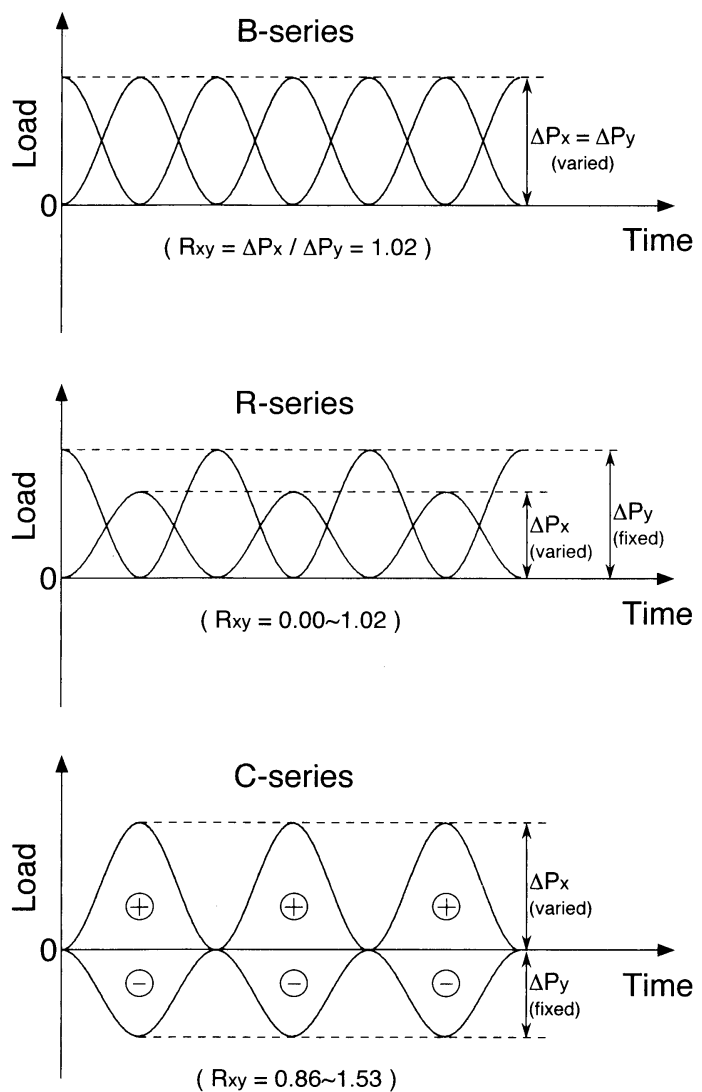

Fig. 5 Illustrations of the biaxial load waves for B-, $\mathrm{R}$ - and $\mathrm{C}$-series.

\begin{tabular}{|c|c|c|c|c|c|c|c|c|c|c|}
\hline Specimen & $\begin{array}{l}\text { Phase } \\
\text { (rad.) }\end{array}$ & $\begin{array}{l}\Delta P_{\mathrm{x}} \\
(\mathrm{kN})\end{array}$ & $\begin{array}{l}\Delta P_{\mathrm{y}} \\
(\mathrm{kN})\end{array}$ & $R_{\mathrm{xy}}$ & $\begin{array}{l}\Delta \sigma_{5} \\
(\mathrm{MPa})\end{array}$ & $N_{\mathrm{c}}$ & $N_{(40 \mathrm{~mm})}$ & $N_{(60 \mathrm{~mm})}$ & $N_{(80 \mathrm{~mm})}$ & $N_{\mathrm{f}}$ \\
\hline B-1 & $\pi$ & 308.2 & 301.9 & 1.02 & 170.4 & $\overline{58395}$ & & & & 503421 \\
\hline B-2 & $\pi$ & 262.0 & 257.3 & 1.02 & 140.3 & 110878 & & & & 713751 \\
\hline B-3 & $\pi$ & 221.0 & 216.9 & 1.02 & 131.1 & 166634 & & & & 1401710 \\
\hline B-4 & $\pi$ & 190.1 & 186.2 & 1.02 & 114.6 & 211233 & & & & 1929590 \\
\hline R-1 & $\pi$ & 317.1 & 311.8 & 1.02 & 195.7 & 97655 & 364980 & 385080 & & 436731 \\
\hline $\mathrm{R}-2$ & $\pi$ & 265.4 & 311.4 & 0.85 & 156.7 & 170769 & 607545 & & 687630 & 705231 \\
\hline $\mathrm{R}-3$ & $\pi$ & 212.6 & 312.5 & 0.68 & 143.7 & 138571 & 797640 & 848970 & & 980751 \\
\hline * $\mathrm{R}-4$ & $\pi$ & 107.7 & 313.2 & 0.34 & 119.2 & - & - & & & 1225400 \\
\hline$* \mathrm{R}-5$ & - & 0.0 & 312.2 & 0.00 & 111.4 & 312622 & - & & & 1162670 \\
\hline C-1 & 0 & 311.5 & 203.7 & 1.53 & 177.8 & 117818 & 434310 & 458205 & & 511701 \\
\hline$C-2$ & 0 & 253.3 & 202.6 & 1.25 & 144.2 & 215000 & 867405 & & 983970 & 1035920 \\
\hline$C-3$ & 0 & 208.7 & 202.5 & 1.03 & 123.2 & 186923 & 1111114 & & 1281705 & 1332110 \\
\hline C-4 & 0 & 174.5 & 203.9 & 0.86 & 105.2 & 903333 & 2358870 & & 2537010 & 2627810 \\
\hline
\end{tabular}

Table 4 Conditions and results of biaxial fatigue tests 
$<\mathrm{B}$ シリーズ, $\Delta P_{\mathrm{x}}=\Delta P_{\mathrm{y}}>$

$\mathrm{x}$-方向荷重レンジ $\Delta P_{\mathrm{x}}$ と $\mathrm{y}$-方向荷重レンジ $\Delta P_{\mathrm{y}}$ をほぼ 等しくし, 位相差 $\pi$ （逆位相）の 2 軸繰り返し引張荷重を 作用させた $\left(\right.$ 既報 $\left.{ }^{2), 3)}\right)$ 。逆位相の $\mathrm{y}$-方向繰り返し引張荷 重は，ポアソン効果により，角回し溶接止端部近傍の $\mathrm{x}^{-}$ 方向応力の下限を押し下げるため, 結果として応力レンジ を増大させる（Fig.6（a）のグレイ部分参照）。

$<\mathrm{R}$ シリーズ, $\Delta P_{\mathrm{x}} / \Delta P_{\mathrm{y}}$ 変化 $>$

$\mathrm{y}$-方向荷重レンジ $\Delta P_{\mathrm{y}}$ を一定とし, $\Delta P_{\mathrm{x}}=0 \sim 317.1 \mathrm{kN}$ について位相差 $\pi$ の 2 軸繰り返し引張荷重試験を行い, 2

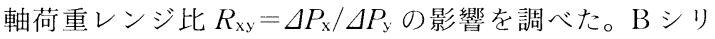
一ズ同様, $\mathrm{y}$-方向繰り返し引張荷重により角回し溶接止 端部近傍の $\mathrm{x}$-方向応力レンジは増大する (Fig. 6(a ))。

$<\mathrm{C}$ シリーズ， $P_{\mathrm{y}}<0>$

$\mathrm{y}$-方向に $\mathrm{x}$-方向繰り返し引張荷重と同位相の繰り返し 圧縮荷重を作用させ，その影響を調べた。荷重は $\Delta P_{\mathrm{y}} を$ 一定とし， $\Delta P_{\mathrm{x}}$ を種々に変化させた。もし残留応力が無け れば，Fig. 6(b)に示す通り，同位相の $\mathrm{y}$-方向繰り返し压 縮荷重はポアソン効果によって角回し溶接止端部近傍の $\mathrm{x}$ 方向応力の上限を押し上げることになるが，Fig. 2 の結 果から，当該箇所では $\mathrm{x}$-方向の引張残留応力によりほほ 降伏しているため頭打ちとなり，実際には除荷時の応力下 限值が低下することによって $\mathrm{x}$-方向応力レンジが増大す る。従って，1サイクル目の $\mathrm{x}$-方向引張荷重負荷時に生 じる $\mathrm{x}$-方向塑性歪の大小や若干のの加工硬化を無視すれば, $\mathrm{y}$-方向繰り返し荷重が角回し溶接止端部近傍の $\mathrm{x}$-方向繰

(a) B- and R-series

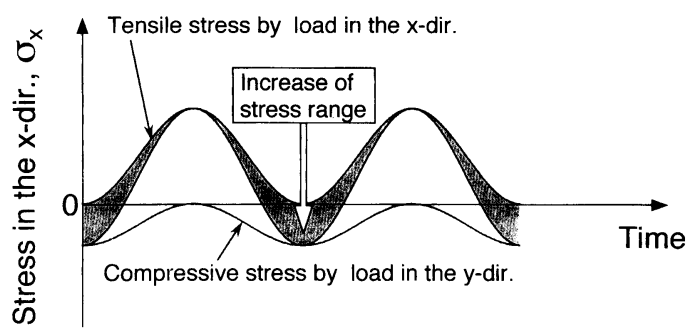

(b) C-series

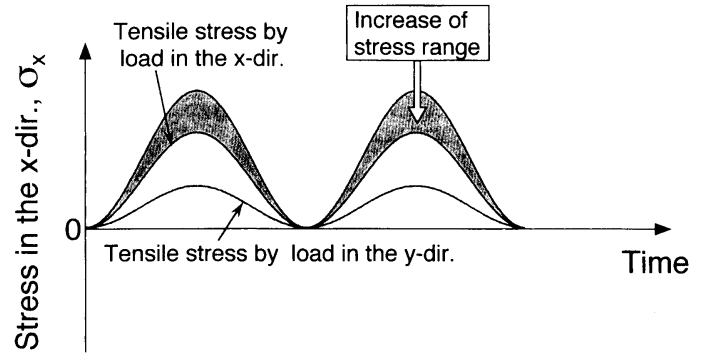

Fig. 6 Illustrations of the stress range increases for (a) $\mathrm{B}^{-}$and $\mathrm{R}$-series and (b) $\mathrm{C}^{-}$-series.
り返し灾打に及ぼす影暃という意味において，Bシリーズ や $\mathrm{R}$ シリーズとほほ同等であるということができる。

2 軸疲労試験について，5\% drop 法によるき裂発生寿命 $N_{\mathrm{c}}$ を, 溶接止端部から $5 \mathrm{~mm}$ の位置に抢ける忍力レンジ $\Delta \sigma_{5}$ で整理した結果を，Fig. 7 にまとめて示す。网中の直 線は（1）式により表される1軸試験結果である。ここで, $\mathrm{R}-4$ 抢よび $\mathrm{R}-5$ 以外の 2 軸疲学試験に招ける参照圭力 $\sigma_{5}$ は, 平面忍力条件を仮定し, 次式から求めている。

$$
\sigma_{5}=\frac{E}{1-\nu^{2}}\left(\varepsilon_{\mathrm{x}}+\nu \varepsilon_{\mathrm{y}}\right)
$$

ここに，Eはヤング率，レはポアソン比， $\varepsilon_{\mathrm{x}}, \varepsilon_{\mathrm{y}}$ は角回し 溶接止端部から $5 \mathrm{~mm}$ の位置における $\mathrm{x}$ 一方向抢よび $\mathrm{y}$ 一 响全の測定値である（註：前報”に扔いては， $\varepsilon_{\mathrm{x}}$ にヤン グ率 $E$ を乗じたものを $\sigma_{5}$ としていたが，Written Discussion（WD）に扔いて，それでは不十分ではないかとの御 指摘を頂いたため，（3)式を用いて忍力を求め，これを $\sigma_{5 \mathrm{~T}}$ として整理し㨁し, 結果をWDへの回答として掲載し た。従つて，前報2) W WD叫答に扔ける $\sigma_{5 \mathrm{~T}}$ が，本報告に おける $\sigma_{5}$ に相当する)。

R-4 扮よびR 5 以外の試験体は，す心゙て角回し溶接止 端部からき裂が発生して $\mathrm{y}$-方向に進展したので，参照応 力 $\sigma_{5}$ として $(3)$ 式から求めた $\mathrm{x}$ 一方向応力を用いている。 一方，R-4 および R-5 は，リブ長手方向の溶接線に沿っ て進展した $\mathrm{x}$ 一方向き裂により破断したため，参照応力 $\sigma_{5}$ としては，リブ長手方向中央部の溶接止端部から $5 \mathrm{~mm}$ の位置（Fig. 3 のB点）に抢ける $\mathrm{y}$-方向応力の FEAに よる計算值を用いた（但し，R-4 はき裂発生簓所近傍の㱏 測定値が無く，5\% drop 法による $N_{\mathrm{c}}$ の特定ができなかっ た)。Fig. 7 を見ると， 2 軸デー夕は 1 軸デー夕の直線を 中心とする一定の分散帯の中に収まって抢り，参照応力レ ンジ $\Delta \sigma_{5}$ による整理が有効であることがわかる。

Table 4 から， 2 軸試験において $N_{\mathrm{c}}$ の $N_{\mathrm{f}}$ に占める割合 を求めると，14.1〜 $34.4 \%$ 範汧で，R-4 を除いて平均す ると $22.5 \%$ ある。一方， $N_{(40 \mathrm{~mm})}$ の $N_{\mathrm{f}}$ に占める割合は

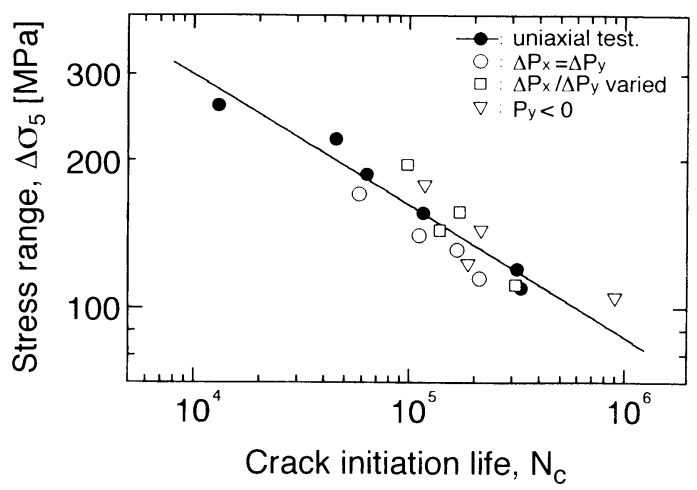

Fig. 7 Results of uniaxial and biaxial fatigue tests, $\Delta \sigma_{5}$ versus $N_{c}$. 


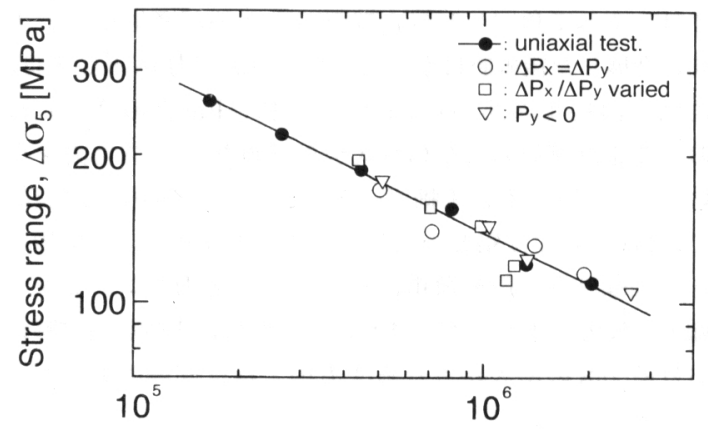

Failure life, $\mathrm{N}_{f}$

Fig. 8 Results of uniaxial and biaxial fatigue tests, $\Delta \sigma_{5}$ versus $N_{f}$

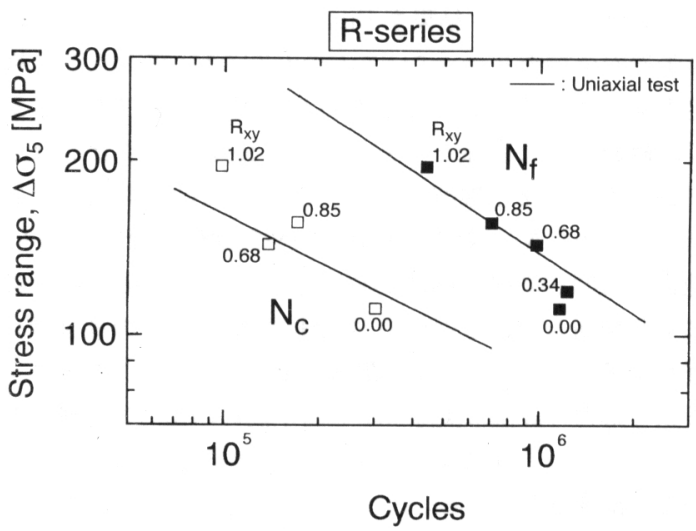

Fig. 9 Effects of biaxial load range ratio.

81.3〜 89.8\%であり，5\% drop 法によってき裂が検出さ れてからき裂長さ $40 \mathrm{~mm}$ に達するまでのき裂伝播寿命が 全寿命に占める割合は比較的大きく， R-4 および R-5 を 除いて平均すると $N_{\mathrm{f}}$ の $62.8 \%$ となる。さて, 大型構造モ デルによる疲労試験等では, き裂の発生を早期に検出する ことが技術的に難しい場合が多く，き裂長さが数十 $\mathrm{mm}$ ，あるいはそれ以上になってから目視により発見され ることもしばしばである。従って，そのような場合のき裂 発見時サイクル数は, 本研究におけるき裂発生寿命 $N_{\mathrm{c}}$ よ りはむしろ $N_{(40 \mathrm{~mm})}$ や $N_{\mathrm{f}}$ の方に近く，大型試験データと 小型試験データとを関連付ける場合には, 寿命の定義に十 分な注意を払う必要があることがわかる。

次に Fig. 8 は, 応力レンジ $\Delta \sigma_{5}$ と破断寿命 $N_{\mathrm{f}}$ の関係を 示している。 $N_{\mathrm{c}}$ の場合よりも更にデータのばらつきは小 さく，1軸データと 2 軸データの相関も良好だが，一部短 寿命側にはずれているデータも見られる。 $\mathrm{B}$ シリーズに関

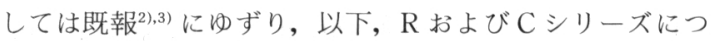
きより詳細な検討を行う。

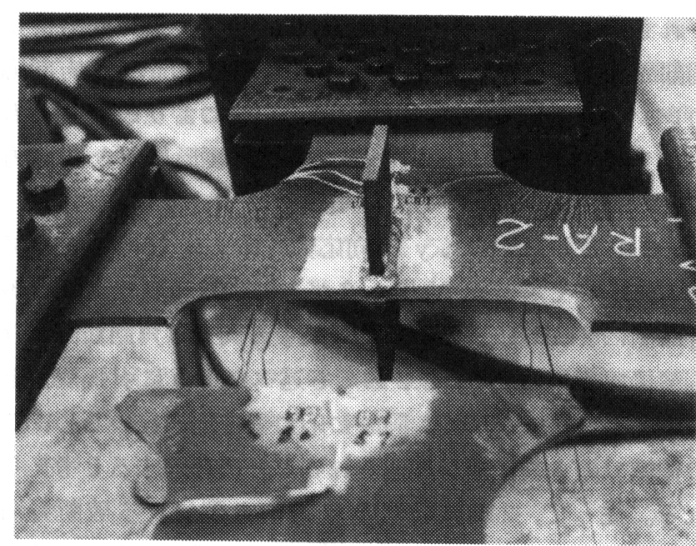

Photo 3 Failure of biaxial fatigue test specimen caused by a fatigue crack in the $\mathrm{y}$-direction $(\mathrm{R}-2)$

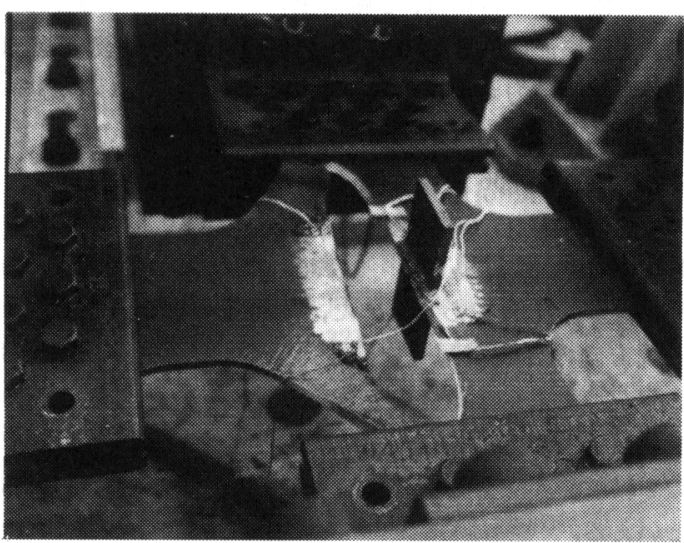

Photo 4 Failure of biaxial fatigue test specimen caused by a fatigue crack in the $\mathrm{x}$-direction $(\mathrm{R}-4)$

\section{2 .12 軸荷重レンジ比の影響（Rシリーズ）}

位相差 $\pi$ の 2 軸繰り返し引張荷重試験における 2 軸荷

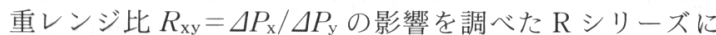
ついて， $N_{\mathrm{c}}$ 扔よび $N_{\mathrm{f}}$ を $\Delta \sigma_{5}$ で整理した結果を，1軸デー 夕（直線）とあわせて Fig. 9 に示す。プロット点近くの

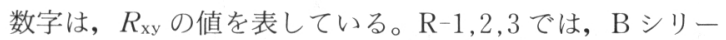
ズと同様, き裂は角回し溶接止端部から発生し, $\mathrm{y}$-方向 にほぼまっすぐ進展した後，破断した（Photo 3)。一方， $\mathrm{R}-4\left(R_{\mathrm{xy}}=0.34\right)$ および $\mathrm{R}-5\left(R_{\mathrm{xy}}=0\right)$ では, Photo 4 に 示すように，き裂はリブ長手方向の溶接止端に沿って発 生・伝播し，そのまま $\mathrm{x}$-方向に進展した後，破断に至っ た。

FEAの結果によれば， $R_{x y}$ が 0.56 を下回ると, Fig. 3 における B 点の $\mathrm{y}$-方向応力レンジが, Fig. 2 における $\mathrm{A}$ 点の $\mathrm{x}$-方向応力レンジを上回る。 $\mathrm{R}-4$ および $\mathrm{R}-5$ は, い 
ずれも $R_{\mathrm{xy}}$ が 0.56 を下回っており, リブ長手方向溶接止 端部の $\mathrm{y}$-方向応カレンジが角回し溶接止端部の $\mathrm{x}$-方向応 カレンジを上回ったため, $\mathrm{x}$-方向き裂により破壊したも のと考えられる。Fig. 9 では，この破壊形態（き裂の方 向）の相違を考慮して, R-4 および R-5については, Fig. 3 の B 点に扔ける $\mathrm{y}$-方向応力を参照応力 $\sigma_{5}$ にとって いる。それでもなお $N_{\mathrm{f}}$ データが 1 軸試験の直線よりも短 寿命側にずれているのは, リブ長手方向では角回し部より も溶接線が長いため, 2.2 節でも述べたように引張残留応 力の大きい領域が広く, 同時に応力集中部も長いため, こ の領域でのき裂伝播が加速されることに起因すると考えら れる。従って，2 軸試験体の $\mathrm{x}$ 一方向き裂による破断寿命 を更に精度良く推定するためには, リブ長手方向が載荷方 向と直交するような，いわゆる横リブ継手の 1 軸疲労試験 データを使用する必要がある。

以上をまとめると, 1 軸疲労試験データから 2 軸疲労寿 命を評価する場合には， 2 軸荷重レンジ比 $R_{\mathrm{xy}}$ の值によっ てまず破壊形態（き裂の方向）を特定し，その破壊形態に 即した参照応力および 1 軸疲労試験デー夕を用いる必要が あるということになる。但し，ここで破壊形態の境目とし ている $R_{\mathrm{xy}}=0.56$ という值は $\mathrm{FE}$ 解析によって得られた 1 つの目安であり, 実験条件としては $R_{\mathrm{xy}}=0.68$ から $R_{\mathrm{xy}}=$ 0.34 へと大きく開いているため, 真の境界を定めるには データが不十分である。また, 荷重条件によっては, $x^{-}$, $\mathrm{y}$-両方向のき裂が同時に発生・伝播し, より複雑な破壊 形態を示すような場合も十分考えられるので, 上で述べた 横リブ継手の 1 軸試験データ収集と併せ, $R_{\mathrm{xy}}=0.56$ 付近 の 2 軸試験データを増やす（密にする）ことが今後の課題 といえる。

3.2.2 横方向繰り返し圧縮荷重の影響（Cシリーズ）

同位相の $\mathrm{y}$-方向繰り返し圧縮荷重の影響を調べた C シ リーズについて， $N_{\mathrm{c}}$ および $N_{\mathrm{f}}$ を $\Delta \sigma_{5}$ で整理した結果を, 1 軸データの直線とあわせて Fig. 10 に示す。Cシリーズ

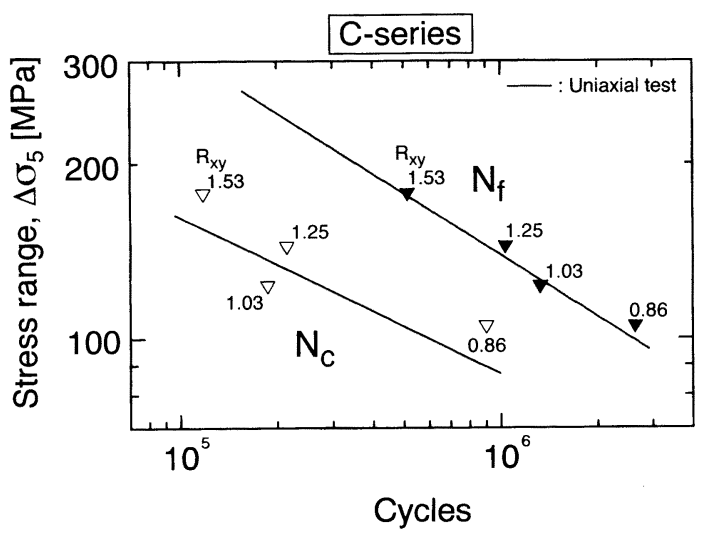

Fig. 10 Effects of cyclic compressive loads in the $\mathrm{y}$-direction.
では，すべて角回し溶接止端部からき裂が発生して $\mathrm{y}$-方 向に進展した後破断に至ったので, 参照応力 $\sigma_{5}$ としては, 角回し溶接止端部から $5 \mathrm{~mm}$ の位置（Fig. 2 の A 点）に おける歪計測值および ( 3 )式から求めた $\mathrm{x}$-方向応力を用 いた。 $N_{\mathrm{c}}, N_{\mathrm{f}}$ ともに 1 軸デー夕と 2 軸デー夕の相関は良好 で，特に $N_{\mathrm{f}}$ では殆ど一致している。すなわち，同位相の $\mathrm{y}$-方向繰り返し圧縮荷重による $\mathrm{x}$-方向応力レンジ $\Delta \sigma_{5}$ の 増大は疲労被害度を増大させ，その度合は 1 軸疲労試験に おける $\Delta \sigma_{5}$ の増大がもたらすものとほぼ同等であるとい うことがわかる。

\section{2 軸試験体の疲労寿命評価}

$\mathrm{x}$-方向，y-方向の荷重值は既知のものとして，FEAに よる参照応力レンジ $\Delta \sigma_{5}$ の推定值と 1 軸疲労試験結果 ((1)式および( 2 )式) を組み合わせ，2 軸試験体の疲労 寿命評価を行った。結果を Fig. 11 に示す。 $N_{\mathrm{c}}$ については 若干過安全評価となっているものもあるが, 全体として推 定寿命と実寿命の比は $1 / 2$ から 2 の間にほぼ収まってお り，概ね良好な評価となっている。 R-4 および R-5 はリ ブ長手方向溶接止端部から発生したx-方向き裂により破 断したため, $N_{\mathrm{r}}$ に対する評価がやや危険側となっている。 他方, 角回し溶接止端部から発生・伝播した $\mathrm{y}$-方向き裂 により破断した，その他の試験体に対する $N_{\mathrm{f}}$ の評価は良 好である。但し, 2.3 節の最後に述べた通り, FEAによ る歪・応力の評価は実際よりも若干高めの值（安全側）と なっており,これによって危険側推定が相殺されているも のも一部含まれている。

Fig. 11 の結果から, 2 軸繰り返し荷重の効果を包含す る参照応力レンジ $\Delta \sigma_{5}$ を適切に選定し, これを用いるこ

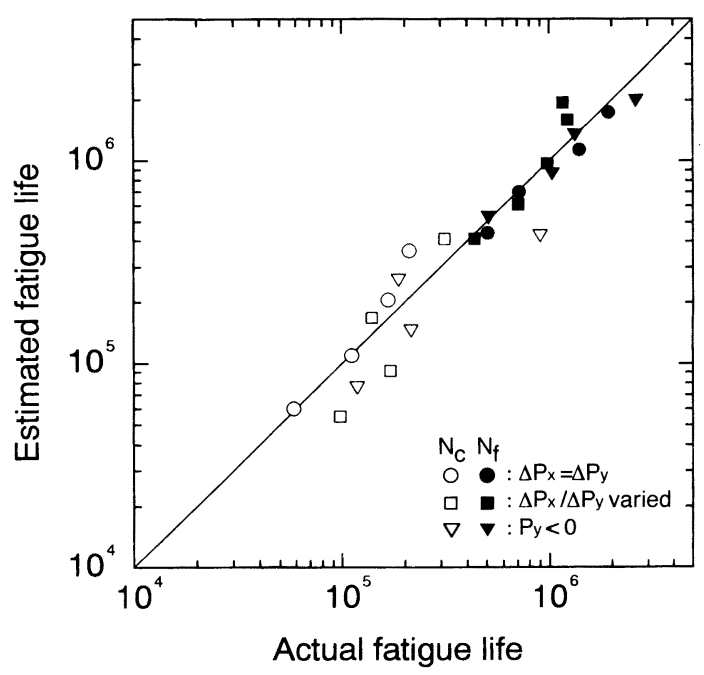

Fig. 11 Fatigue life estimation for biaxial fatigue tests. 
とにより，種々の 2 軸荷重条件について，2 軸疲労試験体 の疲労寿命を FE 解析結果および 1 軸疲労試験データから 統一的に評価し得ることがわかる。

実構造物の疲労寿命評価への適用という観点からみる と, FE 解析等の方法で参照応力を算出する段階で, 多軸 荷重の位相差を考慮しておくことが重要であるということ ができる。本研究で用いた $\mathrm{y}$-方向繰り返し荷重は, 常に 疲労被害度を増大させる方向に働くものであったが, 位相 が $\pi$ ずればかえって寿命が延びる場合もあるわけで, 荷重位相差が寿命評価結果に与える影響は大きい。逆に, 参照応力レンジ $\Delta \sigma_{5}$ の值さえきちんと把握できれば, 溶 接止端部近傍の高い引張残留応力のため, $\mathrm{y}$-方向荷重の 効果は $\Delta \sigma_{5}$ によって定量的に考慮され, 後の議論は比較 的容易となる。但し, ここで問題となるのは, き裂の発生 点および伝播方向が特定できないような場合であり, 本研 究においても, 2 軸荷重レンジ比 $R_{x y}=0.56$ 付近の挙動に 関しては実験点が不足しており, 今後に課題を残してい る。

\section{5. 結論}

本研究で得られた主な結論は以下の通りである。

（1）位相差 $\pi$ の 2 軸繰り返し引張荷重試験において, 2 軸荷重レンジ比 $R_{\mathrm{xy}}$ が 0.56 を下回る荷重条件では, リ ブ長手方向中央における隅肉溶接止端部の $\mathrm{y}$-方向応力 レンジが角回し溶接止端部の $\mathrm{x}$-方向応力レンジを上回 り，試験体はx-方向き裂により破断した。そこで，き 裂伝播方向と直角方向の応力レンジを参照応力レンジ $\Delta \sigma_{5}$ として破断寿命を整理したところ，x-方向き裂によ り破断した 2 軸データは， $\mathrm{y}$-方向き裂により破断した 1 軸および 2 軸データよりも短寿命側となった。これは, リブ長手方向では角回し部よりも溶接線が長く，引張残 留応力や応力集中係数の高い領域が広いため, き裂伝播 が加速されることに起因すると考えられる。

（2） $\mathrm{x}$-方向繰り返し引張荷重と同位相の $\mathrm{y}$-方向繰り返 し压縮荷重は, ポアソン効果により角回し溶接止端部の $\mathrm{x}$-方向応カレンジ $\Delta \sigma_{5}$ を増大させ, 疲労被害度を増大 させる。またこの場合， $\Delta \sigma_{5}$ の増大により疲労被害度が 増大する度合は, 1 軸疲労試験における $\Delta \sigma_{5}$ の増大がも たらすものとほぼ同等であった。

(3) $\mathrm{FE}$ 解析と 1 軸疲労試験データにより, 2 軸疲労試 験体の疲労寿命を推定したところ, 荷重条件によらず, ほぼ妥当な評価が得られた。但し，2 軸疲労試験では, 2 軸荷重レンジ比 $R_{\mathrm{xy}}$ の大小によって破壊形態（き裂の 方向）が変わるので, 参照応力のとり方（位置・方向） および 1 軸疲労試験データの選び方に注意する必要があ る。

\section{謝 辞}

本研究を実施するにあたり, 名古屋大学大学院工学研究 科の貝沼重信氏には, 座屈防止治具の設計に関して貴重な 御助言を賜りました。ここに深甚なる謝意を表します。

\section{参 考 文 献}

1) C. M. Sonsino; Multiaxial fatigue of welded joints under in-phase and out-of-phase local strains and stresses, International Journal of Fatigue, Vol. 17, No. 1, pp. 55-70 (1995).

2）高橋, 高田, 秋山, 牛嶋, 前中：2 軸繰り返し荷重下に おりる角回し溶接継手の疲労挙動, 日本造船学会論 文集 第 184 号, pp. 321-327 (1998).

3) I. Takahashi, M. Ushijima, A. Takada, S. Akiyama and H. Maenaka; Fatigue behaviour of a box-welded joint under biaxial cyclic loads, Fatigue \& Fracture of Engineering Materials \& Structures 22 (10), pp. 869-877 (1999).

4）矢島，川野，多田，井上，阪井，伏見：新制御圧延 (TMCP) 型 50 キロ級高張力鋼溶接継手部の疲労 強度とその評価（その 4)，西部造船会々報 第 83 号, pp. 237-243 (1991).

5）海洋構造物の疲労設計法及び溶接部の品質に関する 研究, SR 202, 日本造船研究協会研究資料第 395 号 (1990). 